\title{
Unravelling the Interactions between Hydrolytic and Oxidative Enzymes in Degradation of Lignocellulosic Biomass by Sporothrix carnis under Various Fermentation Conditions
}

\author{
Olusola A. Ogunyewo and Folasade M. Olajuyigbe \\ Department of Biochemistry, Federal University of Technology, Akure 340001, Nigeria \\ Correspondence should be addressed to Folasade M. Olajuyigbe; folajuyi@futa.edu.ng
}

Received 13 October 2015; Revised 7 December 2015; Accepted 15 December 2015

Academic Editor: Tzi B. Ng

Copyright ( 2016 O. A. Ogunyewo and F. M. Olajuyigbe. This is an open access article distributed under the Creative Commons Attribution License, which permits unrestricted use, distribution, and reproduction in any medium, provided the original work is properly cited.

\begin{abstract}
The mechanism underlying the action of lignocellulolytic enzymes in biodegradation of lignocellulosic biomass remains unclear; hence, it is crucial to investigate enzymatic interactions involved in the process. In this study, degradation of corn cob by Sporothrix carnis and involvement of lignocellulolytic enzymes in biodegradation were investigated over $240 \mathrm{~h}$ cultivation period. About $60 \%$ degradation of corn cob was achieved by S. carnis at the end of fermentation. The yields of hydrolytic enzymes, cellulase and xylanase, were higher than oxidative enzymes, laccase and peroxidase, over $144 \mathrm{~h}$ fermentation period. Maximum yields of cellulase $(854.4 \mathrm{U} / \mathrm{mg})$ and xylanase $(789.6 \mathrm{U} / \mathrm{mg})$ were at 96 and $144 \mathrm{~h}$, respectively. Laccase and peroxidase were produced cooperatively with maximum yields of $489.06 \mathrm{U} / \mathrm{mg}$ and $585.39 \mathrm{U} / \mathrm{mg}$ at $144 \mathrm{~h}$. Drastic decline in production of cellulase at $144 \mathrm{~h}(242.01 \mathrm{U} / \mathrm{mg})$ and xylanase at $192 \mathrm{~h}(192.2 \mathrm{U} / \mathrm{mg})$ indicates that they play initial roles in biodegradation of lignocellulosic biomass while laccase and peroxidase play later roles. Optimal degradation of corn cob (76.6\%) and production of hydrolytic and oxidative enzymes were achieved with $2.5 \%$ inoculum at $\mathrm{pH}$ 6.0. Results suggest synergy in interactions between the hydrolytic and oxidative enzymes which can be optimized for improved biodegradation.
\end{abstract}

\section{Introduction}

Lignocellulosic biomass which is considered to be the mass of organic material from any biological origin or matter has a wide variety of resources available for conversion into bioproducts [1]. These resources can be utilized to create new biomaterials such as fuels, chemicals, animal feeds, soil conditioners, and fertilizers [2]. However, underutilization or ineffective management of these biomasses results in environmental pollution on the earth surface putting humans at various risks [3].

Chemical method of hydrolysis had previously been used for recovery of cellulose from lignocellulosic biomasses but the method is highly expensive and energy intensive as it involves mechanical treatment with acid, alkali, and steam explosion $[4,5]$. This major challenge therefore makes the search for better and efficient method for hydrolyzing lignocellulose through biological means very crucial with the production of lignocellulolytic enzymes.

Cellulase, xylanase, laccase, and peroxidases are extracellular lignocellulolytic enzymes capable of catalysing the biodegradation of lignocellulose. Cellulase, one of the hydrolytic enzymes involved in degradation of lignocellulose, consists of endoglucanases, exoglucanases, and $\beta$ glucosidases which catalyses the hydrolysis of cellulose, a linear polysaccharide polymer with many glucose monosaccharide units not only for liquid fuel production but also for the production of other chemicals which can be potential substitutes for petroleum derivatives $[6,7]$. Xylanase (endo$1,4-\beta$-D-xylanohydrolase) plays important role in depolymerisation of xylan, the main renewable hemicellulosic polysaccharide of plant cell wall. It catalyses the degradation of xylan by cleaving the xylosyl backbone and releasing short xylooligosaccharides, which are further hydrolyzed into 
xylose units by xylan $1,4-\beta$-xylosidase $[8,9]$. Laccases and peroxidases are known oxidoreductive enzymes which are considered to be most effective in the removal of the lignin component of lignocellulose. These lignocellulolytic enzymes have been reported to possess wide applications in textile, paper and pulp, food, chemical, and biobleaching industries and also in biofuel industry for energy generation $[3,10,11]$.

Studies have shown that certain species of white rot fungi (WRF) could achieve efficient biodegradation of lignocellulose with the production of industrially useful oxidoreductive and hydrolytic enzymes when cultivated in appropriate media containing a source of carbon and nitrogen that can stimulate their growth and multiplication [12-14]. WRF are not only capable of producing lignocellulolytic enzymes but also able to penetrate the substrate to transport these enzymes into materials such as wood chips by hyphal extension [15]. However, there is dearth of information on the interaction of lignocellulolytic enzymes from fungal strains in the degradation of lignocellulosic biomass. Furthermore, the mechanism underlying the interaction of the lignocellulolytic enzymes for improved biodegradation of lignocellulose by white rot fungi is unclear. Hence, there is need to examine the interactions of the hydrolytic and oxidative enzymes involved in lignocellulose degradation and the impact of the interaction on the degradation process $[14,16]$ under different fermentation conditions. In this study, we investigated the effect of some process parameters on production of lignocellulolytic enzymes by a white rot fungus and examined how these enzymes interact with one another for improved biodegradation of lignocellulose.

\section{Materials and Methods}

2.1. Materials. Carboxymethyl cellulose, birch wood xylan, 2,2' -azino-di-[3-ethylbenzothiazoline-6-sulphonic acid] (ABTS), dinitrosalicylic acid, sodium-potassium tartrate, bovine serum albumin (BSA), manganese sulphate, copper sulphate, tyrosine, leucine, cellobiose, avicel, xylose, tryptophan, aspartate, glutamate, hydrogen peroxide, and media components were products of Sigma-Aldrich (St Louis, MO, USA). Corn cob was purchased from a local market. The corn cob was sun-dried and powdered into fine particles which was utilized as carbon source in the basal media. Further processing on the powdered corn cob was carried out using standard sieve to an average size of $1 \mathrm{~mm}$. All other chemicals used were of analytical grade.

2.2. Fungal Strain. The microorganism used was a white rot fungus isolated from decaying wood in a selected citrus plantation in Ijare, Ondo State, South West Nigeria. This strain was identified as Sporothrix carnis by the Biotechnology Unit of Federal Institute of Industrial Research, Lagos, based on morphological and biochemical methods described by Collins et al. [17]. The fungal strain was maintained on fresh potato dextrose agar (PDA) slants and stored at $4^{\circ} \mathrm{C}$.

2.3. Inoculum Preparation and Production of Lignocellulolytic Enzymes. Seed culture was prepared by growing a loopful of slant culture in $30 \mathrm{~mL}$ culture medium containing glucose $(10.0 \mathrm{~g} / \mathrm{L})$, ammonium nitrate $(2.0 \mathrm{~g} / \mathrm{L}), \mathrm{KH}_{2} \mathrm{PO}_{4}(0.8 \mathrm{~g} / \mathrm{L})$, $\mathrm{K}_{2} \mathrm{HPO}_{4}(0.2 \mathrm{~g} / \mathrm{L}), \mathrm{MgSO}_{4} \cdot 7 \mathrm{H}_{2} \mathrm{O}(0.5 \mathrm{~g} / \mathrm{L})$, and yeast extract $(2.0 \mathrm{~g} / \mathrm{L})$ in a $200 \mathrm{~mL}$ conical flask with $\mathrm{pH}$ adjusted to 6.0 [10]. The culture was incubated at $30^{\circ} \mathrm{C}$ for $72 \mathrm{hr}$ at $160 \mathrm{rpm}$ in a shaking incubator (Stuart, UK). The 3-day-old seed culture was used as inoculum for the production media. Seed inoculum of $1.5 \mathrm{~mL}$ (constituting $3 \% \mathrm{v} / \mathrm{v}$ ) was transferred into a $50 \mathrm{~mL}$ corn cob based (CCB) media which comprises corn $\operatorname{cob}(10 \mathrm{~g} / \mathrm{L})$, ammonium nitrate $(2.0 \mathrm{~g} / \mathrm{L}), \mathrm{KH}_{2} \mathrm{PO}_{4}(0.8 \mathrm{~g} / \mathrm{L})$, $\mathrm{K}_{2} \mathrm{HPO}_{4}(0.2 \mathrm{~g} / \mathrm{L}), \quad \mathrm{MgSO}_{4} \cdot 7 \mathrm{H}_{2} \mathrm{O}(0.5 \mathrm{~g} / \mathrm{L}), \mathrm{CuSO}_{4} \cdot 5 \mathrm{H}_{2} \mathrm{O}$ $(0.25 \mathrm{~g} / \mathrm{L})$, yeast extract $(2.0 \mathrm{~g} / \mathrm{L})$, and $\mathrm{MnSO}_{4} \cdot 7 \mathrm{H}_{2} \mathrm{O}$ at $\mathrm{pH}$ 6.0. At the end of 192-hour incubation period, cultures were harvested by centrifugation at $10,000 \mathrm{rpm}$ for $15 \mathrm{~min}$ at $4^{\circ} \mathrm{C}$ using refrigerated benchtop centrifuge (Eppendorf 5810R). The cell free supernatant was recovered as crude enzyme preparation and assayed for the presence of cellulase, xylanase, laccase, and total peroxidase.

\subsection{Enzyme Assays}

2.4.1. Determination of Cellulase Activity. The supernatants obtained after biomass separation were analyzed for enzyme activity. Endoglucanase (CMCase) activity was determined using the method described by Wood and Bhat [18] with some modifications. One hundred and fifty microliters $(150 \mu \mathrm{L})$ of enzyme extract was added to $450 \mu \mathrm{L}$ of $1 \%$ (w/v) carboxymethyl cellulose (CMC) in $50 \mathrm{mM}$ sodium acetate buffer $(\mathrm{pH} 4.8)$ in an Eppendorf tube and incubated at $40^{\circ} \mathrm{C}$ for 20 minutes. The reaction was terminated with the addition of $400 \mu \mathrm{L}$ of dinitrosalicylic acid (DNSA) and boiled at $100^{\circ} \mathrm{C}$ for $5 \mathrm{~min}$. The absorbance was recorded at $575 \mathrm{~nm}$ against blank. One unit of CMCase activity was expressed as $1 \mu$ mole of glucose liberated per minute under standard assay conditions.

2.4.2. Determination of Xylanase Activity. Xylanase activity was determined according to the method of Saha [19] with slight modification. The reaction mixture comprised $400 \mu \mathrm{L}$ of $1 \%(\mathrm{w} / \mathrm{v})$ solution of birch wood xylan in $50 \mathrm{mM}$ Tris- $\mathrm{HCl}$ buffer $\mathrm{pH} 9.0$ incubated with $100 \mu \mathrm{L}$ of culture supernatant for $15 \mathrm{~min}$ at $40^{\circ} \mathrm{C}$. The released reducing sugar was assayed using the DNSA method [20]. One unit of xylanase activity was defined as the amount of the enzyme that liberated $1 \mu \mathrm{mol}$ of xylose equivalent per minute under the standard assay conditions.

2.4.3. Determination of Laccase Activity. Laccase activity was determined according to a modified method of Bourbonnais and Paice [21]. This was done by monitoring spectrophotometrically the change in absorbance at $420 \mathrm{~nm}$ $\left(\mathrm{A}_{420}\right)$ related to the rate of oxidation of $1 \mathrm{mM} \mathrm{2,2}{ }^{\prime}$-azinodi-[3-ethylbenzothiazoline-6-sulphonate] (ABTS) in $50 \mathrm{mM}$ sodium acetate buffer ( $\mathrm{pH}$ 3.8). Assays were performed in $1 \mathrm{~mL}$ cuvettes at room temperature with $750 \mu \mathrm{L}$ ABTS and $250 \mu \mathrm{L}$ of enzyme extract. One unit of laccase activity was defined as the amount of enzyme that leads to the oxidation of $1 \mu \mathrm{mol}$ of ABTS per minute with a molar extinction for 
the $A B T S$ radical cation (the reaction product) of $\varepsilon_{420 \mathrm{~nm}}=$ $36000 \mathrm{M}^{-1} \mathrm{~cm}^{-1}$.

2.4.4. Determination of Peroxidase Activity. Total peroxidase activity was assayed according to the method of Hunter et al. [22]. Peroxidase activity was determined via oxidation of $0.24 \mathrm{mM} \mathrm{2,2}$-azino-di-[3-ethylbenzothiazoline-6sulphonate] (ABTS) buffered with $50 \mathrm{mM}$ sodium acetate buffer $\mathrm{pH} 5.0$ in the presence of $5 \mathrm{mM} \mathrm{H}_{2} \mathrm{O}_{2}$ at $414 \mathrm{~nm}$ for $5 \mathrm{~min}$ in a UV/Visible spectrophotometer (Unico). The reaction mixture $(750 \mu \mathrm{L})$ contained equal volume of ABTS, culture supernatant, and $\mathrm{H}_{2} \mathrm{O}_{2}$. One unit $(\mathrm{U})$ of peroxidase activity was defined as the amount of enzyme oxidizing $1 \mu \mathrm{mol}$ ABTS per minute at $\mathrm{pH} 5.0$ and $25^{\circ} \mathrm{C}$ with a molar extinction coefficient for the ABTS radical cation (the reaction product) of $\varepsilon_{414 \mathrm{~nm}}=31100 \mathrm{M}^{-1} \mathrm{~cm}^{-1}$.

2.4.5. Determination of Protein Concentration. Protein concentration was determined by the method of Bradford [23] using bovine serum albumin (BSA) as standard. In the assay, $200 \mu \mathrm{L}$ of diluted dye reagent was pipetted into $10 \mu \mathrm{L}$ of sample solution. The mixture was then incubated at room temperature for 15 minutes to allow proper colour development. The absorbance was measured at $595 \mathrm{~nm}$ against blank. The specific activities of cellulase, xylanase, laccase, and peroxidase were expressed as $\mathrm{U} / \mathrm{mg}$ protein
2.5. Investigation of Interaction of the Lignocellulolytic Enzymes Produced by Sporothrix carnis during Degradation of Corn $\mathrm{Cob}$

2.5.1. Effect of Cultivation Time on Degradation of Corn Cob and Production Dynamics of Lignocellulolytic Enzymes by Sporothrix carnis. Degradation of corn cob with Sporothrix carnis was carried out in a shaking incubator at $155 \mathrm{rpm}$ and $30^{\circ} \mathrm{C}$ in flask containing $100 \mathrm{~mL}$ of the $\mathrm{CCB}$ media. The initial $\mathrm{pH}$ of the CCB media was adjusted to 6.0 prior to autoclaving. The CCB media were inoculated with $3 \%$ inocula of seed cultures and incubated in a shaking incubator at $155 \mathrm{rpm}$. The biodegradation of corn cob and production of enzymes were monitored over $240 \mathrm{~h}$ at $48 \mathrm{~h}$ intervals. At the end of each fermentation period, the fermented medium was filtered and the total biomass consisting of fermented substrate and mycelia was measured using Whatman filter paper to evaluate the degradation of corn cob in the media. The experiments were done in triplicate. The filtrate was thereafter centrifuged at $4^{\circ} \mathrm{C}$ and $6000 \mathrm{rpm}$ for $15 \mathrm{~min}$. The supernatant obtained was used to assay for the activity of lignocellulolytic enzymes according to standard procedures described earlier. The degradation efficiency was calculated as

$\%$ Degradation $=\frac{\text { Initial Weight of biomass before fermentation }- \text { Final Weight of biomass after fermentation }}{\text { Initial Weight of biomass before fermention }} \times 100$.

2.5.2. Effect of Inoculum Size on Degradation of Corn Cob and Production Dynamics of Lignocellulolytic Enzymes by Sporothrix carnis. Effect of varying inoculum size was determined by varying the percentage of inoculum introduced into sterile CCB media. The percentages of inocula used were $1 \%, 2 \%, 2.5 \%, 5 \%, 7.5 \%$, and $10 \%$. Corn cob based media $(50 \mathrm{~mL})$ were prepared and the $\mathrm{pH}$ was adjusted to 6.0 . The media were autoclaved, cooled, and inoculated with $0.3 \mathrm{~mL}$, $0.6 \mathrm{~mL}, 0.75 \mathrm{~mL}, 1.5 \mathrm{~mL}, 2.25 \mathrm{~mL}$, and $3 \mathrm{~mL}$, of the 3 -day-old seed culture of Sporothrix carnis, respectively. The inoculated media were transferred to a shaking incubator and incubated at $155 \mathrm{rpm}$ for $144 \mathrm{~h}$ which was the optimum incubation time obtained for production of lignocellulolytic enzymes during degradation of corn cob by S. carnis. At $144 \mathrm{~h}$, the degradation efficiency was evaluated as described earlier and the fermentation broths were centrifuged and the supernatants were used to assay for the activities of lignocellulolytic enzymes. The experiments were done in triplicate.

\subsubsection{Effect of pH on Degradation of Corn Cob and Production} Dynamics of Lignocellulolytic Enzymes by Sporothrix carnis. The effect of $\mathrm{pH}$ on corn cob degradation was determined by preparing the CCB media at varying $\mathrm{pH}$ of 4.0-10.0. CCB media $(50 \mathrm{~mL})$ were prepared and $\mathrm{pH}$ values of the media were adjusted to 4.0, 5.0, 6.0, 7.0, 8.0, 9.0, and 10.0, respectively. The media were autoclaved and inoculated with $2.5 \%$ of Sporothrix carnis seed culture. The inoculated media were incubated at $30^{\circ} \mathrm{C}$ in a shaking incubator (Stuart) $155 \mathrm{rpm}$ for $144 \mathrm{~h}$ after which the fermentation broths were centrifuged. The supernatants were used to assay for the activity of lignocellulolytic enzymes. The degradation efficiency was determined as earlier described. The experiments were carried out in triplicate.

\section{Results and Discussion}

3.1. Effect of Cultivation Time on Degradation of Corn Cob and Production and Interaction of Lignocellulolytic Enzymes by Sporothrix carnis. Results revealed that $14 \%$ of corn cob was degraded by $48 \mathrm{~h}$ of fermentation (Figure 1). The degradation was observed with the commencement of production of lignocellulolytic enzymes. This shows that enzymes catalyse the breakdown of lignocellulosic components of corn cob into metabolites that Sporothrix carnis utilized for growth [24]. It was observed that, as the cultivation time increased, the degradation increased to $19.87 \%$ at $96 \mathrm{~h}, 27.71 \%$ at $144 \mathrm{~h}$, and $39.47 \%$ at $192 \mathrm{~h}$ and about $60 \%$ degradation was obtained at $240 \mathrm{~h}$. The results showed that the degradation of corn cob increased with time. Analysis of enzyme production shows that the yield of cellulase was highest among the four enzymes 


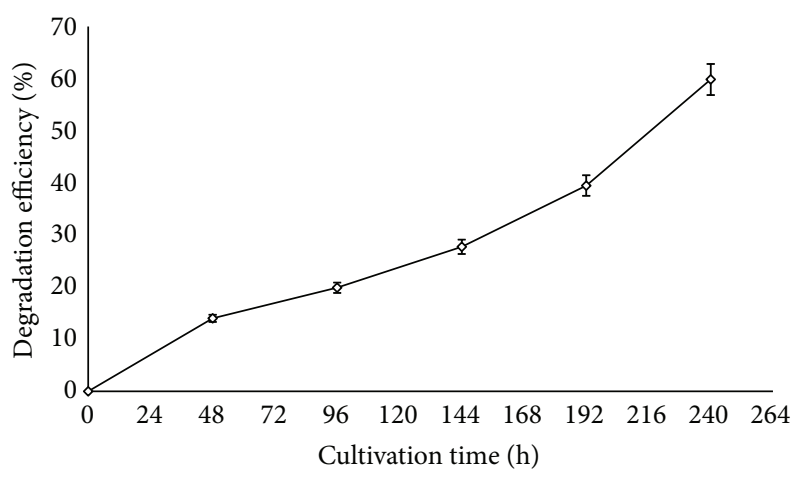

FIGURE 1: Effect of cultivation time on degradation of corn cob by $S$. carnis (error bars represent mean values and standard deviation of triplicate determination).

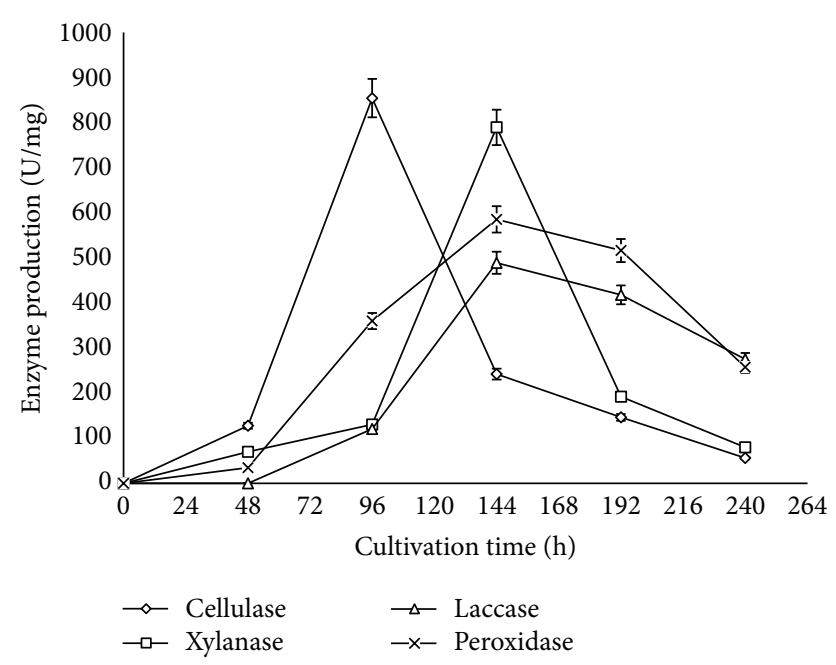

FIGURE 2: Effect of cultivation time on production of lignocellulolytic enzymes (error bars represent mean values and standard deviation of triplicate determination).

assayed at $48 \mathrm{~h}$ (Figure 2). Cellulase was the first enzyme that acted on the corn cob during the degradation as $127.6 \mathrm{U} / \mathrm{mg}$ of it was produced at $48 \mathrm{~h}$, although low amount of xylanase $(69.68 \mathrm{U} / \mathrm{mg})$ and peroxidase $(34.6 \mathrm{U} / \mathrm{mg})$ was obtained at this cultivation time (Figure 2). It was however surprising to observe that laccase was not detected at $48 \mathrm{~h}$. This might be an indication that, in the degradation of lignocellulose, the $\beta$-1,4-bonds in the cellulose component are the first to be hydrolyzed which makes the other components accessible to degradation [6]. The capacity of this fungus to produce high levels of cellulase and xylanase is of importance in supplying the growing culture with a carbon source and nutrients essential for their biosynthetic activity [10].

At $96 \mathrm{~h}$ of cultivation, the degradation efficiency increased to $19.89 \%$ (Figure 1). At this cultivation time, it was observed that cellulase production reached a climax with maximum production of $854.4 \mathrm{U} / \mathrm{mg}$ (Figure 2). This consequently stimulated an increase in xylanase production (specific activity of $130.5 \mathrm{U} / \mathrm{mg}$ ) at $96 \mathrm{~h}$ which was twice the activity recorded at $48 \mathrm{~h}$ of cultivation (Figure 2). It was observed that, as the hydrolysis of the cellulose and hemicellulose component of the corn cob increased, the lignin component became more accessible which was evident with the concerted increase in peroxidase activity. The result showed that laccase production was observed at $96 \mathrm{~h}$ of cultivation with specific activity of $98.2 \mathrm{U} / \mathrm{mg}$ (Figure 2). This suggests that laccase from this organism is not a primary metabolite that the fungus requires for growth as it is produced abundantly in the later phase of the degradation process $[25,26]$.

After $96 \mathrm{~h}$, cellulase activity declined rapidly and the production of the other enzymes (xylanase, peroxidase, and laccase) increased substantially. Optimum production of these three enzymes was obtained at $144 \mathrm{~h}$ (Figure 2) with lignocellulose degradation of $27.7 \%$ (Figure 1). It was surprising to observe that maximum production of xylanase, laccase, and peroxidase was obtained as cellulase production declined. This indicates that the activities of the enzymes in the degradation process depend on the action of cellulase to initiate the process. It could be inferred that the rapid increase observed in the degradation is a result of the generation of many open ends through cellulose hydrolysis which enhanced accessibility to the recalcitrant lignin component of the corn cob [27]. As the cultivation time increased above $144 \mathrm{~h}$, production of hydrolytic enzymes declined (Figure 2). This decline could be a result of exhaustion of glucose and xylose which are primary metabolites obtained from the degradation of corn cob by Sporothrix carnis required for growth. It was observed that, during this period, the yield of oxidative enzymes was still high (516.27 U/mg peroxidase; $417.8 \mathrm{U} / \mathrm{mg}$ laccase) which accounts for increase in degradation efficiency up to $39.5 \%$ and $59.81 \%$ at $192 \mathrm{~h}$ and $240 \mathrm{~h}$ of degradation, respectively.

The results obtained on the production of lignocellulolytic enzymes by $S$. carnis during corn cob degradation support the finding of Kachlishvili et al. in which it was reported that production of these enzymes was optimal at $144 \mathrm{~h}$ of fermentation by some basidiomycetes during fermentation of food wastes [10]. Similarly, Sharma et al. reported maximum xylanase production from Aspergillus sp. at $144 \mathrm{~h}$ of cultivation [28]. However, some fungi have been reported to produce lignocellulolytic enzymes within $120 \mathrm{~h}$ of cultivation, whereas some extend beyond $144 \mathrm{~h}$ [29-31].

\subsection{Effect of Inoculum Size on Degradation of Corn Cob and} Production and Interaction of Lignocellulolytic Enzymes by Sporothrix carnis. Investigation of the effect of inoculum size on corn cob degradation by Sporothrix carnis revealed that the microbial load had an impact on the degradation process. It was observed that the degradation efficiency of Sporothrix carnis increased to $73 \%$ at $144 \mathrm{~h}$ when $2.5 \%$ of the inoculum was used while $59.8 \%$ degradation efficiency was achieved at $240 \mathrm{~h}$ of fermentation when $3 \%$ of the inoculum was used (Figure 3). With the use of $1 \%$ inoculum, $4.03 \%$ degradation of the corn cob was achieved at $144 \mathrm{~h}$. Degradation efficiencies of $44.83 \%, 62.2 \%$, and $58.7 \%$ were obtained with $2 \%, 5 \%$, and $7.5 \%$ inocula, respectively (Figure 3 ). The results revealed that optimum inoculum size is of key importance in degradation 


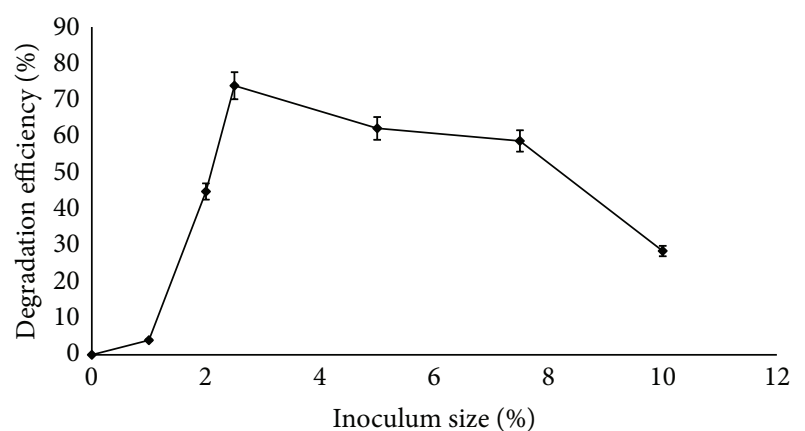

FIGURE 3: Effect of inoculum size on degradation of corn cob by $S$. carnis (error bars represent mean values and standard deviation of triplicate determination).

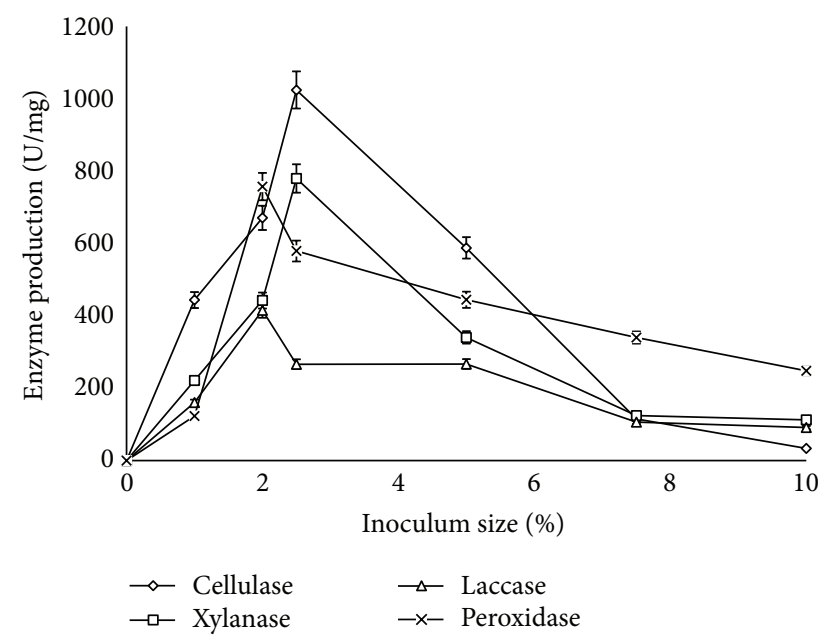

FIGURE 4: Effect of inoculum size on production of lignocellulolytic enzymes (error bars represent mean values and standard deviation of triplicate determination).

studies as lower inoculum size allows microbial culture to multiply at a slower rate and hence insufficient utilization of the substrate to produce metabolites. On the other hand, larger inoculum size results in rapid multiplication of cells that gets the nutrient exhausted quickly with time [24]. Surprisingly, the hydrolytic enzymes were produced optimally when $2.5 \%$ inoculum size was used with cellulase activity of $1024.22 \mathrm{U} / \mathrm{mg}$ and xylanase activity of $779.82 \mathrm{U} / \mathrm{mg}$ while $2 \%$ inoculum size supported the production of the oxidative enzymes with specific activities of $415.45 \mathrm{U} / \mathrm{mg}$ and $757.41 \mathrm{U} / \mathrm{mg}$ for laccase and peroxidase, respectively (Figure 4). Presence of abundant spores in inoculum has been reported to facilitate rapid proliferation and biomass synthesis for enzyme production as was evident with the production of cellulase and xylanase obtained in this study $[32,33]$.

At inoculum sizes above $2.5 \%$, it was observed that there was a decline in the production of the lignocellulolytic enzymes which eventually resulted in rapid decline in the degradation efficiency of $S$. carnis. Previous studies have shown that, beyond a certain inoculum load, enzyme

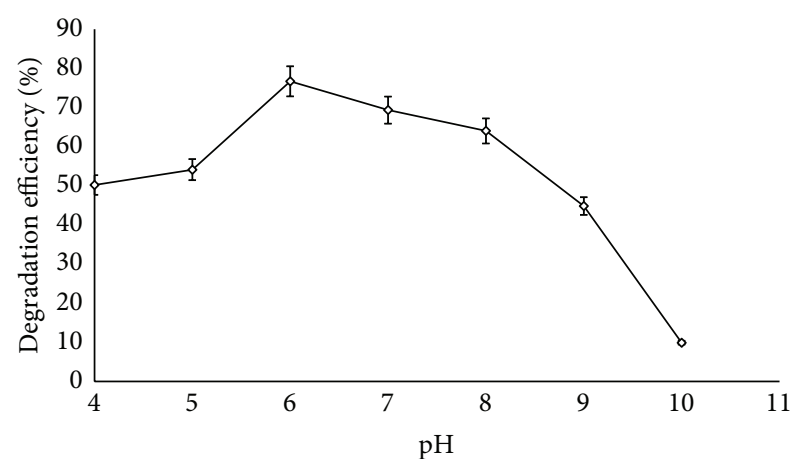

FIGURE 5: Effect of $\mathrm{pH}$ on degradation efficiency of corn cob by $S$. carnis (error bars represent mean values and standard deviation of triplicate determination).

production may decrease due to the depletion of nutrients and developed oxygen tension in the medium resulting from enhanced biomass. These factors may individually or collectively result in decrease of metabolic activity $[34,35]$. Various inoculum sizes have been reported to support the optimum production of these lignocellulolytic enzymes. Reports have shown that lower inoculum sizes favour the production of these enzymes as it was reported that the nutrient and oxygen levels in the fermentation media are sufficient for the growth of fungi and therefore enhanced production of lignocellulolytic enzymes [36]. Gunny et al. [33] reported maximum cellulase production from Aspergillus terreus with $4 \%$ inoculum. Omojasola et al. in their study reported a decline in glucose production by some fungi when cultured on pineapple waste at inoculum sizes above $6 \%$ and $8 \%$ using A. niger and above $4 \%$ and $6 \%$ for fermentations using $T$. longibrachiatum as a result of low yield of cellulase [37]. Niladevi et al. observed an increase in laccase production at inoculum size within $1.0-4.0 \%$ and a decrease at $5 \%$ inoculum size [38]. The increase in the yield of hydrolytic enzymes when $2.5 \%$ inoculum was used over the oxidative enzymes by $S$. carnis could be a reason for the optimum degradation obtained at this inoculum size indicating that the hydrolytic enzymes play a more prominent role in the degradation process than the oxidative enzymes.

\subsection{Effect of pH on Degradation of Corn Cob and Production} and Interaction of Lignocellulolytic Enzymes by Sporothrix carnis. In optimizing various conditions that influence enzymatic degradation of lignocellulosic biomass, $\mathrm{pH}$ was found to be a critical factor that affects the process. The result obtained showed that the degradation of corn cob by $S$. carnis increased with $\mathrm{pH}$ and an optimum degradation of $76.65 \%$ was obtained at $\mathrm{pH} 6.0$ (Figure 5). As the process tends towards the alkaline region, the result revealed that degradation of corn cob declined. It was observed that all the lignocellulolytic enzymes were produced optimally at $\mathrm{pH}$ 6.0 with cellulase being the most abundant one as it had a specific activity of $608.52 \mathrm{U} / \mathrm{mg}$ closely followed by xylanase $(517.6 \mathrm{U} / \mathrm{mg})$ and peroxidase $(412.89 \mathrm{U} / \mathrm{mg})$ and the least was laccase with a maximum specific activity of $360.6 \mathrm{U} / \mathrm{mg}$ 


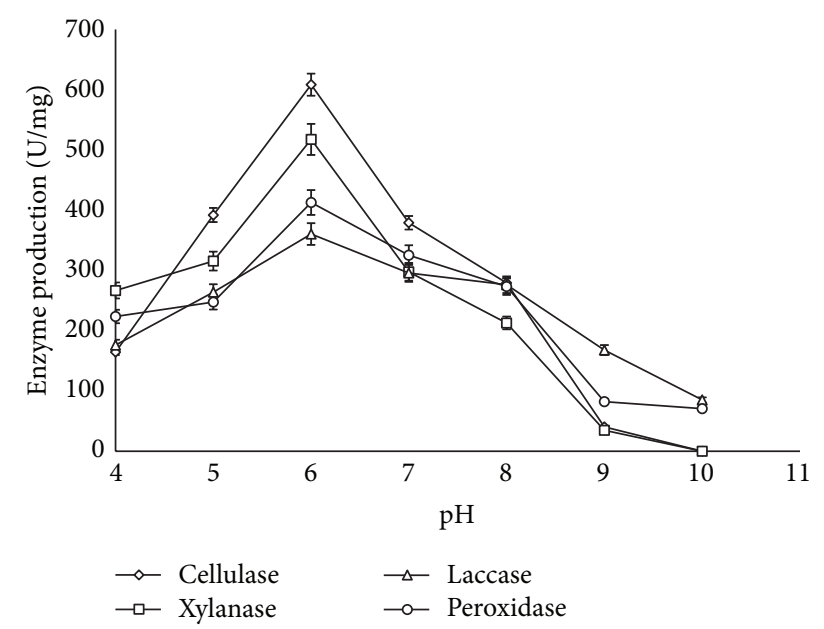

FIGURE 6: Effect of $\mathrm{pH}$ on production of lignocellulolytic enzymes (error bars represent mean values and standard deviation of triplicate determination).

(Figure 6). As the $\mathrm{pH}$ increased in the alkaline region, it was observed that the production level of the enzymes decreased which resulted in lower degradation efficiency. At $\mathrm{pH} 10.0$ when none of the hydrolytic enzymes was detected, the degradation efficiency was only $10 \%$.

The overproduction of the hydrolytic enzymes under this condition as compared with the oxidative enzymes confirmed that the hydrolytic enzymes perform a primary and critical role in lignocellulose degradation [26]. Also, an optimum production of the hydrolytic and oxidative enzymes at $\mathrm{pH}$ 6.0 suggests the existence of synergistic interaction between the hydrolytic and oxidative enzymes which enhanced the degradation efficiency by $S$. carnis. The result revealed that degradation of lignocellulose depends more on the action of the hydrolytic enzymes to initiate the degradation enabling access to the recalcitrant lignin component during the degradation process. Furthermore, the result suggests that the mechanism of action of the oxidative enzymes depends more on the action of the hydrolytic enzymes $[25,26]$.

Previous reports on other ligninolytic fungi show that maximum cellulase production was in the acidic region. Maximum cellulase activity of $0.925 \mathrm{U} / \mathrm{mL}$ at a $\mathrm{pH}$ of 4 was observed by Acharya et al. when they used Aspergillus niger for the solid state fermentation of sawdust [39]. Sohail et al. reported maximum cellulase activity at a $\mathrm{pH}$ of 4 for Aspergillus niger [40]. Sugarcane waste was fermented for cellulase production via solid state fermentation using Aspergillus niger and Trichoderma viride at optimum $\mathrm{pH}$ of 4.5 [41]. Ilyas et al. reported optimum $\mathrm{pH}$ of 4.5 in their studies for cellulase production optimization [42]. Toor and Ilyas also found that cellulase was produced in higher yield in acidic region with optimum production at $\mathrm{pH} 4.0$ which corresponded to the maximum degradation of cellulosic chickpea agro waste substrate [43]. Similarly, optimum $\mathrm{pH}$ of 4.0 and 5.0 had been reported for maximum yield of crude lignin modifying enzymes by Coriolus hirsutus and Trametes villosa, respectively [44]. Wen et al. reported the optimum
$\mathrm{pH}$ of 5.0 for manganese peroxidase production from P. chrysosporium [45]. Similarly, Yasmeen et al. reported that acidic conditions support lignin modifying enzymes from Schizophyllum commune and Ganoderma lucidum [46]. Results obtained from this study showed that acidic condition favours the degradation process and production of lignocellulolytic enzymes by Sporothrix carnis is in a synergistic manner under this condition which enhanced better degradation of the corn cob under study.

\section{Conclusion}

The results from this study have given some insights into the synergistic interactions between hydrolytic and oxidative enzymes involved in the degradation of lignocellulosic biomass. The absence of any of these lignocellulolytic enzymes could adversely affect the degradation process. Improved degradation of the lignocellulose in the study was achieved by optimizing process parameters for efficient production of lignocellulolytic enzymes.

\section{Conflict of Interests}

The authors declare that there is no conflict of interests.

\section{References}

[1] C. Gupta, P. Jain, D. Kumar, A. K. Dixit, and R. K. Jain, "Production of cellulase enzyme from isolated fungus and its application as efficient refining aid for production of security paper," International Journal of Applied Microbiology and Biotechnology Research, vol. 3, no. 1, pp. 11-19, 2015.

[2] R. E. H. Sims, W. Mabee, J. N. Saddler, and M. Taylor, "An overview of second generation biofuel technologies," Bioresource Technology, vol. 101, no. 6, pp. 1570-1580, 2010.

[3] W. Du, C. Sun, J. Liang, Y. Han, J. Yu, and Z. Liang, "Improvement of laccase production and its characterization by mutagenesis," Journal of Food Biochemistry, vol. 39, no. 1, pp. 101-108, 2015.

[4] H. M. N. Iqbal, G. Kyazze, and T. Keshavarz, "Advances in the valorization of lignocellulosic materials by biotechnology: an overview," BioResources, vol. 8, no. 2, pp. 3157-3176, 2013.

[5] D. Wesenberg, I. Kyriakides, and S. N. Agathos, "White-rot fungi and their enzymes for the treatment of industrial dye effluents," Biotechnology Advances, vol. 22, no. 1-2, pp. 161-187, 2003.

[6] S. P. Shah, K. S. Kalia, and J. S. Patel, "Optimization of cellulase production by Penicillium oxalicum using banana agrowaste as a substrate," The Journal of General and Applied Microbiology, vol. 61, no. 2, pp. 35-43, 2015.

[7] B. Kaur, S. Bhatia, and U. Phutela, "Production of cellulases from Humicola fuscoatra MTCC 1409: role of enzymes in paddy straw digestion," African Journal of Microbiology Research, vol. 9, no. 9, pp. 631-638, 2015.

[8] Y. Takahashi, H. Kawabata, and S. Murakami, "Analysis of functional xylanases in xylan degradation by Aspergillus niger E-1 and characterization of the GH family 10 xylanase XynVII," SpringerPlus, vol. 2, article 447, 2013. 
[9] R. Gaur and S. Tiwari, "Isolation, production, purification and characterization of an organic-solvent-thermostable alkalophilic cellulase from Bacillus vallismortis RG-07," BMC Biotechnology, vol. 15, article 19, 2015.

[10] E. Kachlishvili, T. Khardziani, E. Metreveli, A. Kobakhidze, and V. Elisashvili, "Screening of novel basidiomycetes for the production of lignocellulolytic enzymes during fermentation of food wastes," Journal of Waste Conversion, Bioproducts and Biotechnology, vol. 1, no. 1, pp. 9-15, 2012.

[11] E. Kachlishvili, E. Metreveli, and V. Elisashvili, "Modulation of Cerrena unicolor laccase and manganese peroxidase production," SpringerPlus, vol. 3, article 463, 2014.

[12] J. C. Agunwamba, L. I. Ezeogu, and I. Chukwu, "Effects of nutrient, crude oil, and Pseudomonas concentrations I: bacteria growth," International Journal of Global Environmental Issues, vol. 3, pp. 101-112, 2004.

[13] J. Xu, "Bioremediation of crude oil contaminated soil by petroleum-degrading active bacteria," in Introduction to Enhanced Oil Recovery (EOR) Processes and Bioremediation of Oil-Contaminated Sites, L. Romero-Zerón, Ed., chapter 8, InTech, 2012.

[14] E. M. Woolridge, "Mixed enzyme systems for delignification of lignocellulosic biomass," Catalysts, vol. 4, no. 1, pp. 1-35, 2014.

[15] C. Raghukumar, D. D'Souza-Ticlo, and A. K. Verma, “Treatment of colored effluents with lignin-degrading enzymes: an emerging role of marine-derived fungi," Critical Reviews in Microbiology, vol. 34, no. 3-4, pp. 189-206, 2008.

[16] E. Fernández-Fueyo, R. Castanera, F. J. Ruiz-Dueñas et al., "Ligninolytic peroxidase gene expression by Pleurotus ostreatus: differential regulation in lignocellulose medium and effect of temperature and pH," Fungal Genetics and Biology, vol. 72, pp. 150-161, 2014.

[17] C. H. Collins, M. Patricia, and J. M. Grage, Collins and Lynes Microbiological Methods, Butterworth-Geubnmann Publishers, London, UK, 6th edition, 1991.

[18] T. M. Wood and K. M. Bhat, "Method for measuring cellulase activities," in Methods in Enzymology, W. A. Wood and J. A. Kellogg, Eds., vol. 160 of Cellulose and Hemicellulose, pp. 87-112, Academic Press, New York, NY, USA, 1998.

[19] B. C. Saha, "Production, purification and properties of xylanase from a newly isolated Fusarium proliferatum," Process Biochemistry, vol. 37, no. 11, pp. 1279-1284, 2002.

[20] G. L. Miller, "Use of dinitrosalicylic acid reagent for determination of reducing sugar," Analytical Chemistry, vol. 31, no. 3, pp. 426-428, 1959.

[21] R. Bourbonnais and M. G. Paice, "Oxidation of non-phenolic substrates. An expanded role for laccase in lignin biodegradation," FEBS Letters, vol. 267, no. 1, pp. 99-102, 1990.

[22] C. L. Hunter, R. Maurus, M. R. Mauk et al., "Introduction and characterization of a functionally linked metal ion binding site at the exposed heme edge of myoglobin," Proceedings of the National Academy of Sciences of the United States of America, vol. 100, no. 7, pp. 3647-3652, 2003.

[23] M. M. Bradford, "A rapid and sensitive method for the quantitation of microgram quantities of protein utilizing the principle of protein-dye binding," Analytical Biochemistry, vol. 72, no. 1-2, pp. 248-254, 1976.

[24] S. Bhattacharya, A. Das, A. Patnaik, P. Bokade, and S. Sundara Rajan, "Submerged fermentation and characterization of carboxymethyl cellulase from a rhizosperic isolate of Trichoderma viride associated with Azadirachta indica," Journal of Scientific and Industrial Research, vol. 73, no. 4, pp. 225-230, 2014.
[25] V. Elisashvili, E. Kachlishvili, and M. Penninckx, "Effect of growth substrate, method of fermentation, and nitrogen source on lignocellulose-degrading enzymes production by whiterot basidiomycetes," Journal of Industrial Microbiology and Biotechnology, vol. 35, no. 11, pp. 1531-1538, 2008.

[26] V. Elisashvili, E. Kachlishvili, N. Tsiklauri, E. Metreveli, T. Khardziani, and S. N. Agathos, "Lignocellulose-degrading enzyme production by white-rot Basidiomycetes isolated from the forests of Georgia," World Journal of Microbiology and Biotechnology, vol. 25, no. 2, pp. 331-339, 2009.

[27] G. P. K. Reddy, G. Narasimha, K. D. Kumar, G. Ramanjaneyulu, A. Ramya, and B. S. S. Kumari, "Cellulase production by Aspergillus niger on different natural lignocellulosic substrates," International Journal of Current Microbiology and Applied Sciences, vol. 4, pp. 835-845, 2015.

[28] S. Sharma, S. Vaid, and B. J. Bajaj, "Screening of thermo-alkali stable fungal xylanases for potential industrial applications," Current Research in Microbiology and Biotechnology, vol. 3, no. 1, pp. 536-541, 2015.

[29] Y.-M. Tao, X.-Z. Zhu, J.-Z. Huang et al., "Purification and properties of endoglucanase from a sugar cane bagasse hydrolyzing strain, Aspergillus glaucus XC9," Journal of Agricultural and Food Chemistry, vol. 58, no. 10, pp. 6126-6130, 2010.

[30] S. Kavitha and P. Nagarajan, "Production of endoglucanase by Aspergillus niger using agro residue," Journal of Engineering Resource, vol. 3, pp. 89-96, 2011.

[31] V. K. Nathan, M. E. Rani, G. Rathinasamy, K. N. Dhiraviam, and S. Jayavel, "Process optimization and production kinetics for cellulase production by Trichoderma viride VKF3," SpringerPlus, vol. 3, article 92, 2014.

[32] M. O. Allimoun, M. R. Ananzeh, and K. M. Khleifat, "Screening selection and optimization of extracellular methanol and ethanol tolerant lipase from Acinetobacter sp. K5b4," International Journal of Biosciences, vol. 6, no. 10, pp. 44-56, 2015.

[33] A. A. N. Gunny, D. Arbain, P. Jamal, and R. E. Gumba, "Improvement of halophilic cellulase production from locally isolated fungal strain," Saudi Journal of Biological Sciences, vol. 22, pp. 476-483, 2015.

[34] P. Kashyap, A. Sabu, A. Pandey, G. Szakacs, and C. R. Soccol, "Extra-cellular L-glutaminase production by Zygosaccharomyces rouxii under solid-state fermentation," Process Biochemistry, vol. 38, no. 3, pp. 307-312, 2002.

[35] R. A. Abusham, R. N. Z. R. A. Rahman, A. Salleh, and M. Basri, "Optimization of physical factors affecting the production of thermo-stable organic solvent-tolerant protease from a newly isolated halo tolerant Bacillus subtilis strain Rand," Microbial Cell Factories, vol. 8, article 20, 2009.

[36] S. N. Baharum, A. B. Salleh, C. N. A. Razak, M. Basri, M. B. A. Rahman, and R. N. Z. R. A. Rahman, "Organic solvent tolerant lipase by Pseudomonas sp. strain S5: stability of enzyme in organic solvent and physical factors affecting its production," Annals of Microbiology, vol. 53, no. 1, pp. 75-83, 2003.

[37] P. F. Omojasola, O. P. Jilani, and S. A. Ibiyemi, "Cellulase production by some fungi cultured on pineapple waste," Nature and Science, vol. 6, no. 2, pp. 64-79, 2008.

[38] K. N. Niladevi, R. K. Sukumaran, and P. Prema, "Utilization of rice straw for laccase production by Streptomyces psammoticus in solid-state fermentation," Journal of Industrial Microbiology \& Biotechnology, vol. 34, no. 10, pp. 665-674, 2007.

[39] P. B. Acharya, D. K. Acharya, and H. A. Modi, "Optimization for cellulose production by Aspergillus niger using saw dust as 
substrate," African Journal of Biotechnology, vol. 7, no. 22, pp. 4147-4152, 2008.

[40] M. Sohail, R. Siddiqi, A. Ahmad, and S. A. Khan, "Cellulase production from Aspergillus niger MS82: effect of temperature and pH," New Biotechnology, vol. 25, no. 6, pp. 437-441, 2009.

[41] A. A. Juwaied, A. A. H. Al-Amiery, Z. Abdumuniem, and U. Anaam, "Optimization of cellulase production by Aspergillus niger and Trichoderma viride using sugar cane waste," Journal of Yeast and Fungal Research, vol. 2, pp. 19-21, 2011.

[42] U. Ilyas, A. Majeed, K. Hussain, K. Nawaz, S. Ahmad, and M. Nadeem, "Solid State fermentation of Vignamungo for cellulase production by Aspergillus niger," World Applied Science Journal, vol. 12, pp. 1172-1178, 2011.

[43] Y. Toor and C. U. Ilyas, "Optimization of cellulase production by Aspergillus ornatus by the solid state fermentation of Cicer arietinum," American Journal of Research Communication, vol. 2, no. 1, pp. 125-141, 2014.

[44] R. Yamanaka, C. F. Soares, D. R. Matheus, and K. M. G. Machado, "Lignolytic enzymes produced by Trametes villosa CCB176 under different culture conditions," Brazilian Journal of Microbiology, vol. 39, no. 1, pp. 78-84, 2008.

[45] X. Wen, Y. Jia, and J. Li, "Enzymatic degradation of tetracycline and oxytetracycline by crude manganese peroxidase prepared from Phanerochaete chrysosporium," Journal of Hazardous Materials, vol. 177, no. 1-3, pp. 924-928, 2010.

[46] Q. Yasmeen, M. Asgher, M. A. Sheikh, and H. Nawaz, "Ligninolytic enzymes by RSM," Bioresources, vol. 8, pp. 944-968, 2013. 

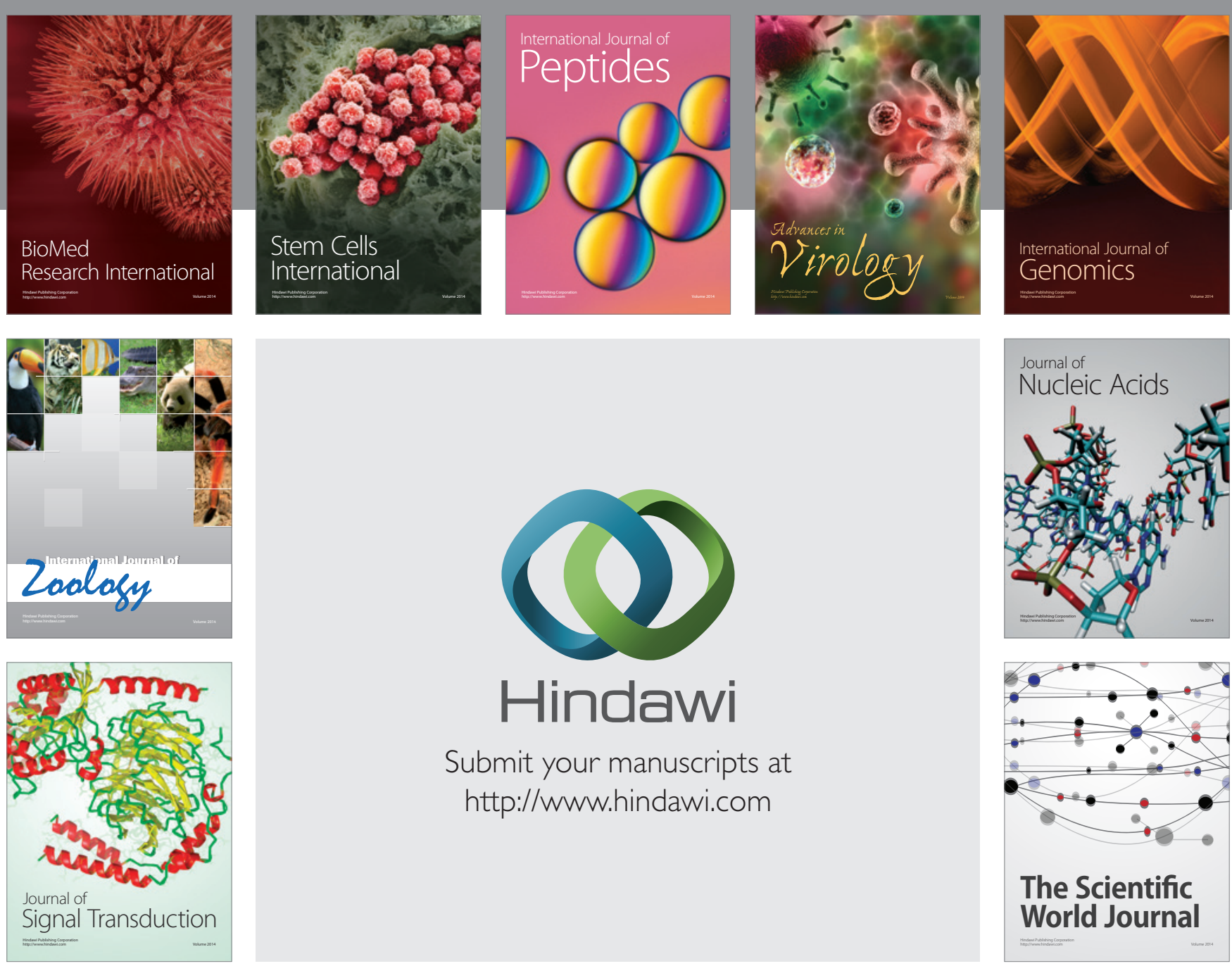

Submit your manuscripts at

http://www.hindawi.com
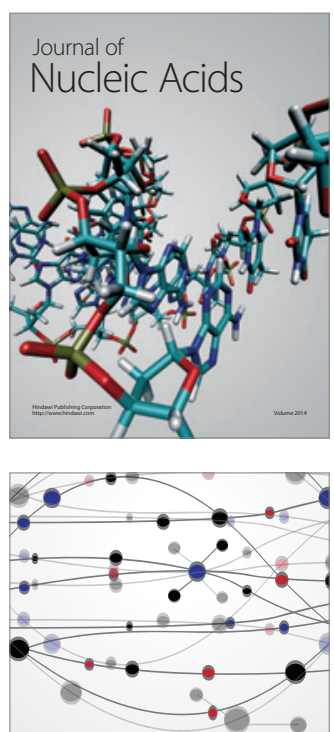

The Scientific World Journal
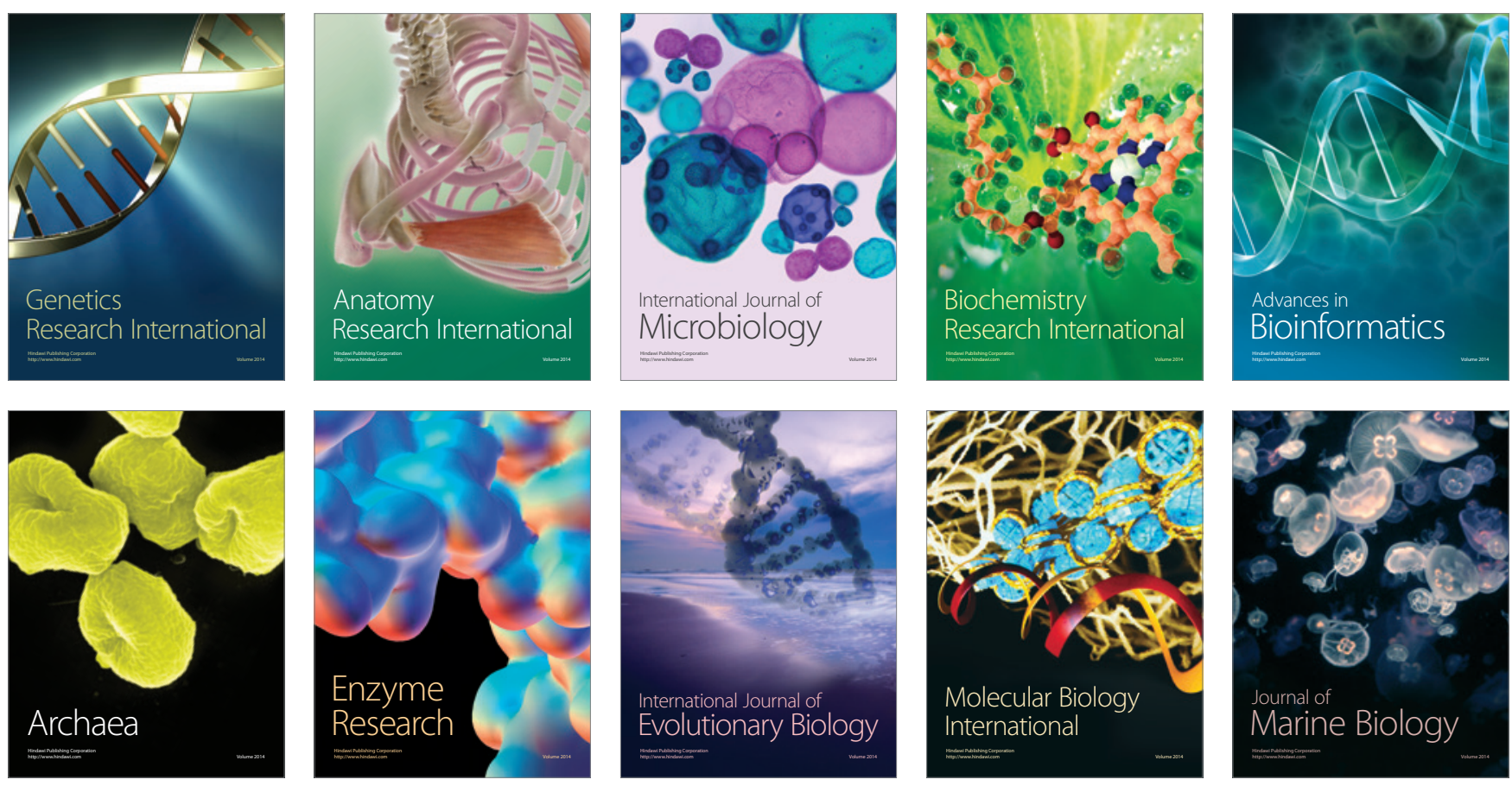